\title{
Hydrological Modeling of an Ungauged River Basin Using SWAT Model for Water Resource Management Case of Kayanga River Upstream Niandouba Dam
}

\author{
Issa Lèye ${ }^{1, ~ *}$, Soussou Sambou ${ }^{1}$, Moussé Landing Sané ${ }^{1}$, Ibrahima Ndiaye ${ }^{1}$, Didier Maria Ndione ${ }^{1}$, \\ Seïdou Kane ${ }^{1}$, Samo Diatta ${ }^{2}$, Raymond Diédhiou ${ }^{1}$, Mohamed Talla Cissé ${ }^{3}$ \\ ${ }^{1}$ Department of Physics, Faculty of Sciences and Technology, University Cheikh Anta Diop, Dakar-Fann, Senegal \\ ${ }^{2}$ Department of Physics, University of Assane Seck, Ziguinchor, Senegal \\ ${ }^{3}$ Faculty of Technological Sciences, University of Thies, Thies, Senegal
}

Email address:

dinaissaleye10@gmail.com (I. Lèye)

${ }^{*}$ Corresponding author

\section{To cite this article:}

Issa Lèye, Soussou Sambou, Moussé Landing Sané, Ibrahima Ndiaye, Didier Maria Ndione, Seïdou Kane, Samo Diatta, Raymond Diédhiou, Mohamed Talla Cissé. Hydrological Modeling of an Ungauged River Basin Using SWAT Model for Water Resource Management Case of Kayanga River Upstream Niandouba Dam. Journal of Water Resources and Ocean Science. Vol. 9, No. 1, 2020, pp. 29-41. doi: $10.11648 /$ j.wros.20200901.14

Received: January 21, 2020; Accepted: February 21, 2020; Published: March 10, 2020

\begin{abstract}
Hydrological modeling of ungauged basins is important and imperative for policymakers and stakeholders in water management. The Kayanga river upstream from the Niandouba dam is subject to extreme pressure caused by natural and anthropogenic factors. The hydro system Niandouba Dam and Confluent Dam are used to providing water for the irrigated perimeters in Anambe. Since there is no data available to evaluate the water resources entering the Niandouba Dam, we used Soil and Water Assessment Tools (SWAT) to set up a hydrological model in the ungauged basin of Kayanga river upstream Niandouba dam. A regionalization approach has been used to predict the river discharge at Niandouba watershed upstream of the Niandouba dam. SWAT model has been calibrated from 01/01/2001 to 31/12/2001 and validated from 01/01/2002 to $31 / 12 / 2002$, with a daily scale on the Koulountou watershed. During the calibration period, the criteria of goodness of fit are respectively 0.87 for Nash-Sutcliffe Efficiency coefficient (NSE), 0.87 for coefficient of determination (R2), $-1.6 \%$ for Percent Bias (PBIAS) and 0.36 for Standard Deviation Ratio (RSR). In the validation period, we have found a Nash-Sutcliffe Efficiency coefficient (NSE) of 0.62, a coefficient of determination (R2) of 0.77, a Percent Bias (PBIAS) of $+35.9 \%$, Standard Deviation Ratio (RSR) of 0.62 . These parameters have been used to generate flows at the entrance of the Niandouba Dam.
\end{abstract}

Keywords: Hydrological Modeling, SWAT, Niandouba Dam, Kayanga River, Ungauged, Irrigation, Calibration, Validation

\section{Introduction}

Water is a key resource for sustainable economic and social development. Senegal's economic growth depends mainly on rain-fed agriculture which is one of the largest sectors in the country. Distribution over time and space of rain becomes then of paramount importance. Because of climate change and climate variability, water shortages have become the major crises of sustainable development of agriculture in Senegal. Senegalese authorities have made water management a priority and place it in a very good position among the strategies of poverty reduction. This initiative led to the creation of the Manantali-Diama hydro system in the Senegal River watershed, and the KayangaAnambé hydro-system in the Gambia River watershed [1]. The first was entrusted to OMVS, the second to SODAGRI. SODAGRI was created in 1974 by the State of Senegal, under the supervision of the Ministry of Agriculture and Rural Equipment [2]. One of the missions of this company is the control of water in the South East and South of Senegal The Kayanga-Anambe hydraulic system is the driving force of this mission The network of this hydro system is constituted by the Kayanga River, which has its source in the 
Republic of Guinea Bissau and extends over a catchment area of $1755 \mathrm{~km}^{2}$, and its tributary, the Anambe River, that flows entirely in Senegal and covers an area of $1100 \mathrm{~km}^{2}$ [3]. The hydro system includes two dams: the confluence dam in the Anambe basin, with a holding capacity of 60 million cubic meters of water, the Niandouba dam in the Kayanga basin, which has a holding capacity of 90 million cubic meters, and the threshold of the Kounkané bridge, with 25 million cubic meters. This threshold allows stopping the water flowing out of Lake Waïma [4]. The entire system is intended for overflow irrigation in the rainy season. During the off-season, it is completed by a network of canals and a set of pumping stations. Irrigation consumes a large amount of freshwater and often creates water scarcity.

Water supply systems such as dams are built within mind the assumptions that past and future climatic trends will be the same [5]. But current climate change and variability impacts precipitation globally and poses a dire threat to water resource management. Rainfall and stream flood play a significant role in the hydrological cycle and are essential to global socio-economic activities [5]. Stream flood is important for flood control, hydropower, navigation, and ecological factors and in balanced agriculture watersheds [6]. So, understanding water resources availability would help stakeholders and policymakers to plan and develop an area [7], while IWRM allows coordinating different stakeholders sharing water resources in river basins [6]. A hydroclimatic modeling approach is carried out to assess the impacts of human activities on the different hydrological processes [5]. In recent years, hydrologists and resource managers apply more and more hydrologic models as a tool to understand and manage ecological and human activities that affect watershed systems [8]. Hydroclimatic models need to be calibrated first and then validated using observed streamflow data. Unfortunately, in many cases, these data are not available or are insufficient. Such catchments are considered as ungauged [9]. The planning and the management of the water resources in the ungauged catchment may be undermined by the unavailability of observed data [9]. One of the main challenge's hydrologists and water resource managers face is the estimation of streamflow in ungauged catchments. Hydrological models sometimes have a great number of parameters that need to be calibrated before application to a specific basin. For the ungauged basin, this calibration is not possible to lack observed data. To overcome this problem, various regionalization techniques based on a similarity approach and/or a statistical approach have been developed to estimate streamflow in ungauged catchments. In the statistical approach statistical relationships between catchment attributes, such as topography, soil, drainage area, etc., and the optimized model parameter is established to determine the parameters of an ungauged basin using its catchment attributes. The other method of regionalization is based on the similarity approach. One or more donor gauged catchments, similar to receptor catchment are identified. The similarity regionalization approach assumes that similar catchments behave hydrologically similarly. So, the definition of the similarity measure, certainly subjective, will condition the success of the selected regionalization approach [9].

Basins that require water resource planning often suffer from lack of enough hydrometric stations for surface runoff measurement, or incomplete data of measurement stations. In such basins, hydrological models can simulate the rainfallrunoff process and evaluate runoff from precipitation with minimum cost and time by simulating the rainfall-runoff process [10]. Hydrologists use various hydrological models to estimate water resources availability (e.g., lumped models, physically distributed models, empirical models, and statistical models). Physical distributed hydrological models can simulate water balance by using spatial variables (mainly soils, land-uses, topography) and climate conditions. New approaches in modeling systems are increasingly relying on geographic information systems (GIS) that have made simulation possible over large areas, and on database management systems such as Microsoft Access to support modeling and analysis. Several hydrological and hydraulic models on the watershed scale have been observed. HECHMS (Hydrologic Modeling System), who is designed to simulate the complete hydrologic processes of dendritic basin systems [11]. MIKE SHE (European Hydrological System), simulates dynamic groundwater and surface water interaction and seamlessly integrates all other important hydrological processes at basin scale [12]. TOPMODEL (TOPography based MODEL), allows relatively simple use of Digital Terrain Models (DTM) [13], and can spatially predict basin responses. ATHYS (Atelier HYdrologique Spatialisé), aims to bring together in a friendly and homogeneous environment a set of hydrological models associated with hydroclimatic and geographical data processing [14].

One of the most suitable distributed models used worldwide to study hydrologic processes on the watershed scale is the Soil and Water Assessment Tool (SWAT) $[15,16$, 17]. The Soil and Water Assessment Tool (SWAT) was developed in the United States by the Agricultural Research Service and by Texas A \& M University. It is a conceptual mathematical, semi-physical, semi-distributed, continuoustime model that operates through daily data. It allows us to considers the interconnection of different physical processes occurring in a watershed through the GIS environment [18]. SWAT (Soil and Water Assessment Tool) model is a basinscale model that improves the accuracy of the simulated result of streamflow from rainfall and physical properties of the basin by integrating ArcGIS. SWAT has been tested in various world climates from arid and semi-arid regions to humid and tropical areas; it can simulate water resources in large scales to regional scales [7].

The SWAT model has been successfully applied to watershed-scale projects in different parts of the world with satisfactory results [19]. Reference [20] calibrated, evaluated and applicated SWAT2009 model for simulation of the hydrology of the Xedone River basin. Reference [18] has used the SWAT model for the edaphoclimatic conditions of the Mucuri River Basin located in the Northeast region of 
Minas Gerais, Brazil as well as to test its performance. Reference [19] evaluate the application of the SWAT model in the Jaguarí River Basin, using the previously calibrated set of parameters. The hypothesis is that calibrated parameters can be transferred from neighboring basins, with analogous catchment area, and under the same geological and pedological characteristics. Reference [9] utilizes the SWAT model to check for how can Maps uncertainty of donor catchments be propagated through regionalization schemes based on the similarity approach, and how does it affect the prediction uncertainty in ungauged catchments? Specific questions are as follows: (1) is the selected hydrological model suitable for reproducing the hydrology in the ungauged catchment? (2) How does parameter uncertainty affect model prediction uncertainty in the ungauged catchment through the regionalization scheme? Reference [6] analyzes the differences in streamflow prediction of an ungauged watershed using SWAT by varying the threshold areas for Sub basin delineation and HRU distribution.

The Niandouba Dam has been built on the Kayanga River to supply water for irrigation in the Anambe basin. This Dam plays an important role in the Kayanga Anambe Hydro system. Water Resources Management and Planification. Unfortunately, there is no stream gauge in the Kayanga River basin and only one rain gauge. This basin can be considered as an ungauged basin. This poses the problem of evaluating the inputs to the Dam. The objective of this paper is to use a hydrological model to calculate streamflow inputs to the Dam. As a generalization approach, we have selected the similarity-based one. The swat model has been calibrated and validated in the neighboring Koulountou River basin. Thus, obtained parameters have been used to generate input stream flow to the Niandouba Dam.

\section{Material and Methods}

\subsection{Study Area}

The area of study is the Kayanga River system upstream of the Niandouba Dam and the Koulountou River Basin at the PNNK (NiokoloKoba Bridge). The Kayanga River Basin upstream of Niandouba Dam is located between latitude $12^{\circ} 31$ at $13^{\circ} 09 \mathrm{~N}$ and longitude $13^{\circ} 20$ at $14^{\circ} 26 \mathrm{~W}$; its area is of $6596.45 \mathrm{~km}^{2}$. Koulountou River Basin at PNNK is located between latitude $13^{\circ} 16$ at $11^{\circ} 52 \mathrm{~N}$ and $13^{\circ} 44$ at $12^{\circ} 29 \mathrm{~W}$ over an area of $2143.98 \mathrm{~km}^{2}$ (figure 1). The Kayanga River basin upstream of the Niandouba Dam originates west of the Badiar Plateau (Republic of Guinea) in swamps at an altitude of about 90 m [21]. Koulountou River Basin at PNNK, which is the main tributary of the left bank of the Gambia River, is part of the natural and administrative boundary of the Kolda and Tambacounda regions. It has its source in the northern foothills of Fouta-Djallon at 800 meters altitude on the Mali massif [22]. The climate is Sudano-Guinean in the southern part and Sudano-Sahelian in the northern part. The rainfall regime combines two seasons: one rainy, from May to October, and the other dry spell, the rest of the year. Rainfall decreases from south to north, depending on the monsoon flux. The average monthly temperature at the Kolda synoptic station is maximum in May $\left(32.1^{\circ} \mathrm{C}\right)$ and minimum in December $\left(24.4^{\circ} \mathrm{C}\right)$. The relative humidity reaches its maximum in September and a minimum in January. The average annual of the precipitation decreases regularly from south $(985 \mathrm{~mm})$ to north $(790 \mathrm{~mm})$.

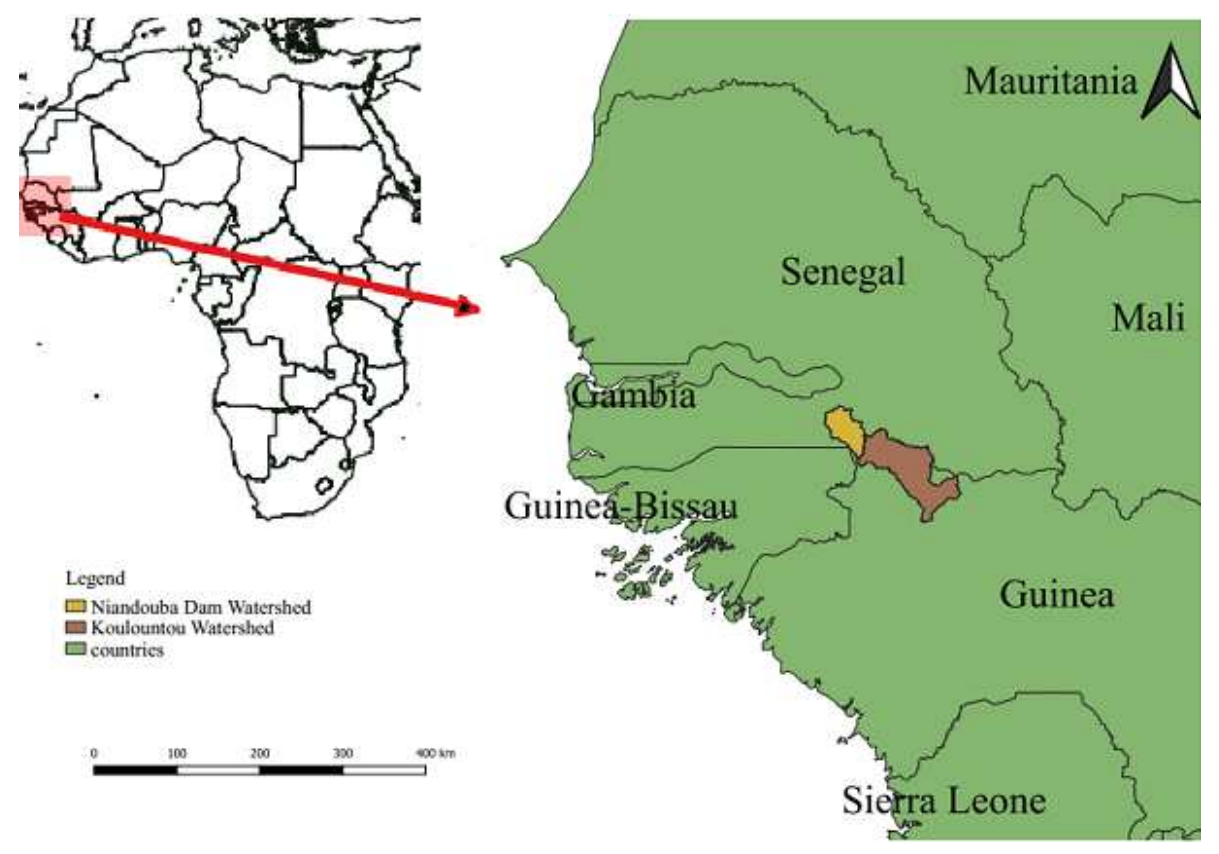

Figure 1. Localization of the studied watersheds.

\subsection{SWAT Model Description}

SWAT [16] is a physically-based semi-distributed, agro- hydrological model [23]. It has been developed by the Agricultural Research Service (ARS) of the United States 
Department of Agriculture (USDA) [24] for application to large and complex watersheds over long periods of time [25]. SWAT can predict the impact of land management practices on water quantity and quality and it is used to simulate water balance, sediment, nutrient and pesticide transport at a basinscale on a daily time step $[17,26]$. SWAT model uses hydrological response units (HRUs). The HRUs is the result of a unique combination of land-use, soil, and slope class in a watershed [27]. The SWAT system is integrated with a Geographical Information System (GIS) and there are three types of SWAT extensions: ArcSWAT for ArcGIS interface, QSWAT for QGIS interface and MWSWAT for MapWindow interface [28]. In this study, we used the ArcSWAT of the ArcGIS interface. SWAT model estimates relevant hydrological components such as evapotranspiration, surface runoff and peak rate of runoff, groundwater flow and sediment yield for each HRU. The water balance is simulated in two separate components: the land phase and the routing phase [7]. The land phase predicts hydrologic components that include surface runoff, evapotranspiration, groundwater, lateral runoff, and return flow. The routing phase is the movement of water, sediments, nutrients, and organic chemicals through the basin channel network to the outlet [29]. The land phase of the hydrological cycle of the SWAT model is based on the water balance equation (1) [30]:

$$
S W_{t}=S W_{0}+\sum_{i=1}^{t}\left(R_{\text {day }}-Q_{\text {surf }}-E_{a}-w_{\text {seep }}-Q_{g w}\right)
$$

where $S W_{t}$ is the final soil water content $\left(\mathrm{mm} \mathrm{H}_{2} \mathrm{O}\right), S W_{0}$ is the initial soil water content on day $i\left(\mathrm{~mm} \mathrm{H}_{2} \mathrm{O}\right), t$ is the time $\left(\mathrm{mm} \mathrm{H}_{2} \mathrm{O}\right), R_{\text {day }}$ is the amount of rainfall on day $i(\mathrm{~mm}$ $\left.\mathrm{H}_{2} \mathrm{O}\right), Q_{\text {surf }}$ is the amount of surface runoff on day $i(\mathrm{~mm}$ $\left.\mathrm{H}_{2} \mathrm{O}\right), E_{a}$ is the amount of actual total evaporation on day $i$ $\left(\mathrm{mm} \mathrm{H}_{2} \mathrm{O}\right), w_{\text {seep }}$ is the amount of water entering the vadose zone from the soil profile on day $i\left(\mathrm{~mm} \mathrm{H}_{2} \mathrm{O}\right)$, and $Q_{g w}$ is the amount of groundwater flow on day $i\left(\mathrm{~mm} \mathrm{H}_{2} \mathrm{O}\right)$.

The setup of the SWAT model consists of five steps: data preparation, basin, and sub-basin discretization, HRU definition, sensitivity analysis, calibration, and validation [31].

\subsection{Data input}

The spatially distributed data (GIS input) needed for the ArcSWAT interface include the meteorological data, the Digital Elevation Model (DEM), soil data, land use, and stream network layers [20]. The digital elevation model is obtained from the NASA (Shuttle Radar Topography Mission SRTM). The digital soil map is prepared from the Soil Map of the World. The land-use map is provided by the Global Land Cover 2000 Project. The climatic data including daily precipitation, maximum and minimum temperature, relative humidity, solar radiation, and wind speed are obtained from the IRD database, while runoff data are issued from the Water Resources Management and Planning Office (Dakar, Senegal) database. All the sources of input data required to run SWAT are summarized in (Table 1).

Table 1. Swat input database.

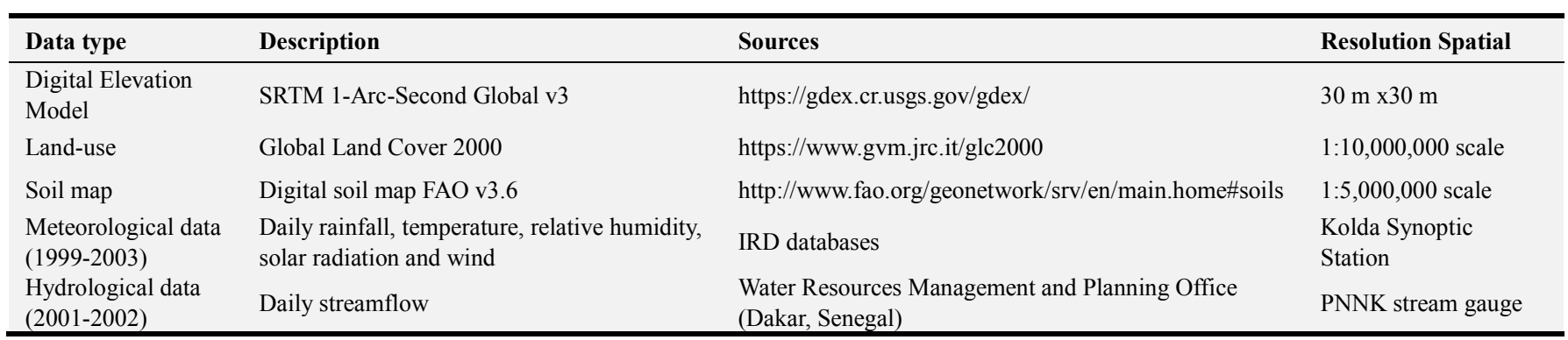

\subsection{Morphometric Characteristics}

\subsubsection{DEM Model}

The use of the DEM makes it possible to delimit the two transboundary watersheds (Figure 2) and the automatic extraction of the parameters morphometrics characterizing the relief.

Morphometric analysis is referring as the quantitative evaluation of form characteristics of the earth surface and any landform unit. In general, the watersheds are selected for the morphometric analysis in the following: Linear Aspect, Areal Aspect and Relief Aspect.

1. Area and perimeter

Being the first and most important feature. The area (A) is the portion of the plane delimited by the crest line or contour of the watershed. Its measurement is made by using a planimeter or by the method of small squares. Basin perimeter $(\mathrm{P})$ is the outer boundary of the watershed that enclosed its area. It is measured along the divides between watersheds and may be used as an indicator of watershed size and shape.

2. Compactness Coefficient

It is used to express the relationship of a hydrologic basin to that of a circular basin having the same area as the hydrologic basin. A circular basin is the most susceptible from a drainage point of view because it will yield shortest time of concentration before peak flow occurs in the basin. The compactness Coefficient $C_{c}$ is calculated using, as in

$$
C_{c}=0.28 P . A^{-1 / 2}
$$

$\left(C_{c}\right)$ : Compactness Coefficient

$(A)$ : Area in $\mathrm{km}^{2}$

$(P)$ : Perimeter in $\mathrm{km}$

3. Basin length 
The basin length is the longest dimension of the basin parallel to the principal drainage line. it is obtained by (3)

$$
L=A^{1 / 2} \frac{C_{c}}{1.12}\left[1+\sqrt{1-\left(\frac{1.12}{C_{c}}\right)^{2}}\right]
$$

$(L)$ : Basin Length in $\mathrm{km}$

4. Average altitude

The average altitude is deduced directly from the hypsometric curve or from the reading of a topographic map. It can be defined, as in

$$
Z_{\text {moy }}=\sum \frac{A_{i} h_{i}}{A}
$$

(Zmoy): Average altitude in $\mathrm{m}$

5. Height difference

The determination of the overall slope index requires knowledge of the useful height difference. It is obtained by the difference between the altitude corresponding to $95 \%$ of the total area of the watershed and the altitude corresponding to $5 \%$ of the total area of the watershed, as in

$$
D=Z_{5 \%}-Z_{95 \%}
$$

(D): height difference

6. overall slope index

The overall slope index is used to classify the catchment area. we take the points such that the upper or lower surface is equal to $5 \%$ of $\mathrm{A}$. It is obtained as in

$$
I_{g}=\frac{D}{L}
$$

$\left(I_{g}\right)$ : overall slope index

7. Specific height difference

Unlike the overall index, the specific height difference then is independent of the surface and compares the basins of different sizes. It is obtained as in

$$
D_{s}=I_{g} \cdot \sqrt{S}
$$

$\left(D_{s}\right)$ : Specific height difference

\section{Drainage density}

The drainage density is the total length of the hydrographic network per unit area of the watershed. The drainage density depends on the geology of the topographic characteristics of the watershed and on the climatological and anthropic conditions. It is obtained as in

$$
D_{d}=\frac{\sum l_{i}}{A}
$$

$\left(D_{d}\right)$ : Drainage density in $\mathrm{km} / \mathrm{km}^{2}$

The details of the morphometric analysis and comparison of drainage basin characteristics of the Koulountou River Basin at PNNK and of Kayanga River basin at Niandouba Dam entrance are presented in Table 2. According to this table, there is a significant difference between the geometric parameters (area, perimeter, basin length) and topographic parameter (height difference, overall slope index, specific height difference) of these two basins, But the two basins have the same form and the drainage density.

Hypsometric curves provide a synthetic view of the slope of the basins. This curve represents the distribution of the surface of the watershed according to its altitude (Figure 3 (a) and Figure 3 (b)). The hypsometric curve is a reflection of the potential dynamic equilibrium state of a basin. The hypsometric curve of the Koulountou River Basin at PNNK is typical of a sedimentary basin while the hypsometric curve of the Kayanga River basin at Niandouba Dam entrance indicates a basin with great erosive potential.



(a)



(b)

Figure 2. Digital elevation model (DEM) of: (a) the Niandouba Dam watershed and (b) the Koulountou watershed. 


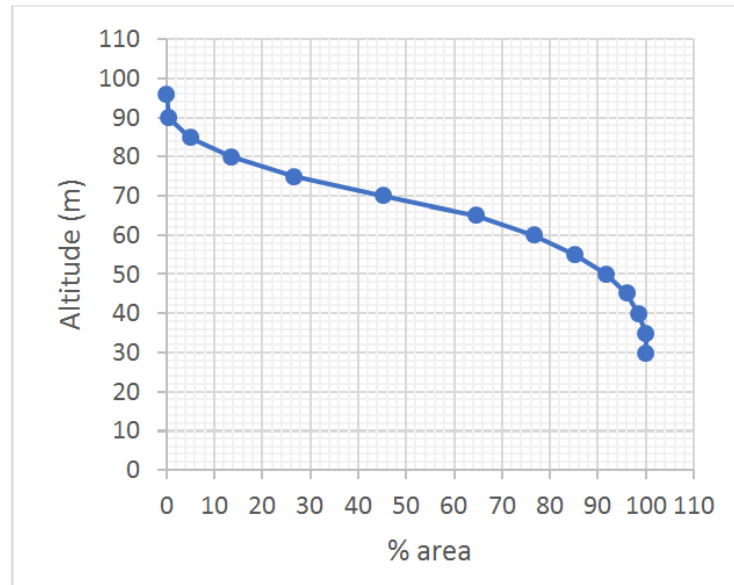

(a)

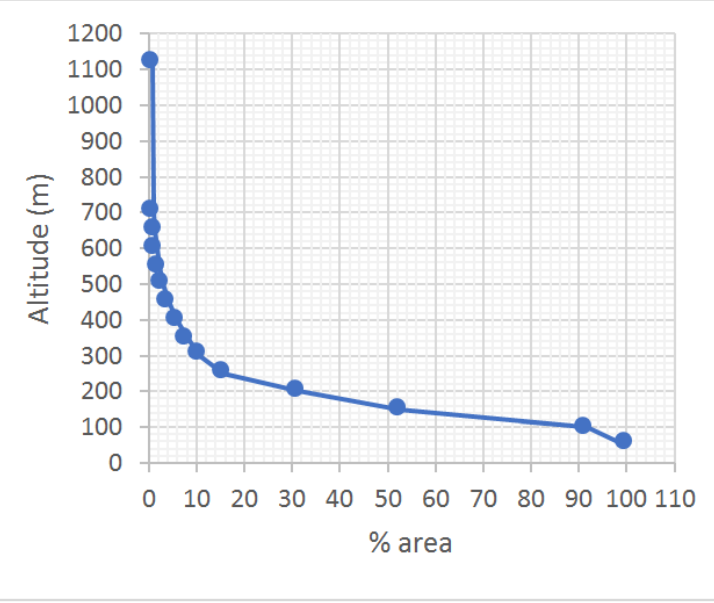

(b)

Figure 3. Hypsometric curves of: (a) Kayanga River basin at Niandouba Dam entrance and (b) Koulountou River Basin at PNNK.

Table 2. Comparison of the morphometric parameters.

\begin{tabular}{llll}
\hline Morphometric Parameters & Formula & Koulountou River Basin at PNNK & Kayanga River basin at Niandouba Dam entrance \\
\hline Area $(\mathrm{A})$ in $\mathrm{km}^{2}$ & ArcGIS & 6597 & 2144 \\
Perimeter $(\mathrm{P})$ in $\mathrm{km}$ & ArcGIS & 938 & 475 \\
Compactness coefficient $\left(C_{c}\right)$ & Equation $(2)$ & 3.23 & 2.87 \\
Basin Length $(L)$ in $\mathrm{km}$ & Equation $(3)$ & 483 & 246 \\
Minimum altitude $\left(\mathrm{Z}_{\min }\right)$ in m & ArcGIS & 16 & 23 \\
Maximum altitude $\left(\mathrm{Z}_{\max }\right)$ in m & ArcGIS & 1113 & 96 \\
Median altitude $\left(\mathrm{Z}_{\operatorname{med}}\right)$ in m & hypsometric curve & 106 & 64 \\
height difference $(D)$ & Equation (5) & 345 & 39 \\
overall slope index $\left(I_{g}\right)$ & Equation (6) & 0.71 & 0.16 \\
Specific height difference $\left(D_{s}\right)$ & Equation $(7)$ & 58.04 & 7.34 \\
Drainage density $\left(D_{d}\right)$ in $\mathrm{km} / \mathrm{km}^{2}$ & Equation $(8)$ & 0.20 & 0.24 \\
\hline
\end{tabular}

\subsubsection{Land Use}

Land use and soil type activity are intimately related, and their combined actions have a singular influence on surface flow. The land-use map is illustrated in Figure 4. the comparison of classification and use of Koulountou River Basin at PNNK and of Kayanga River basin at Niandouba
Dam entrance are present in Table 3. it can be noted that the two basins have the same land use except for the AGRL and the WWGR in the Kayanga River basin at Niandouba Dam entrance but are in the Koulountou River Basin at PNNK with a small percentage. the RNGB and the FRSDO together occupy more than $95 \%$ of the basin's land use.

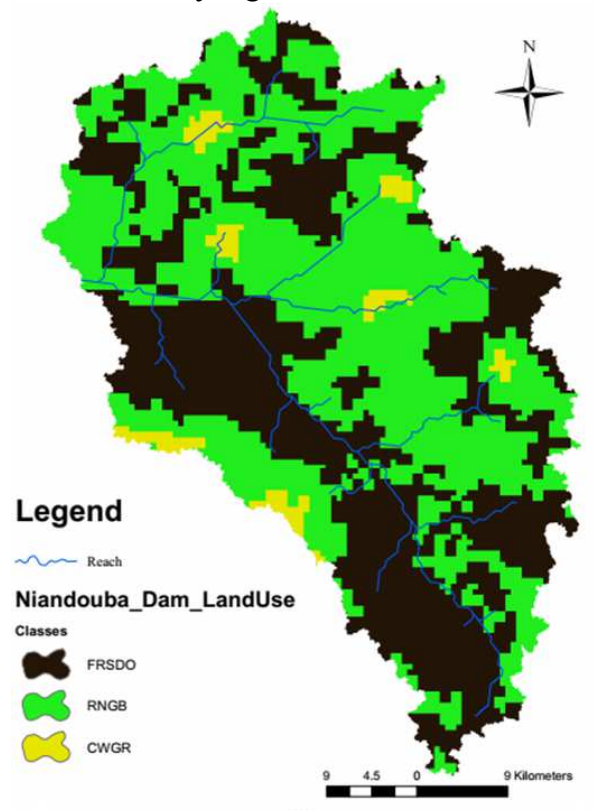

(a)

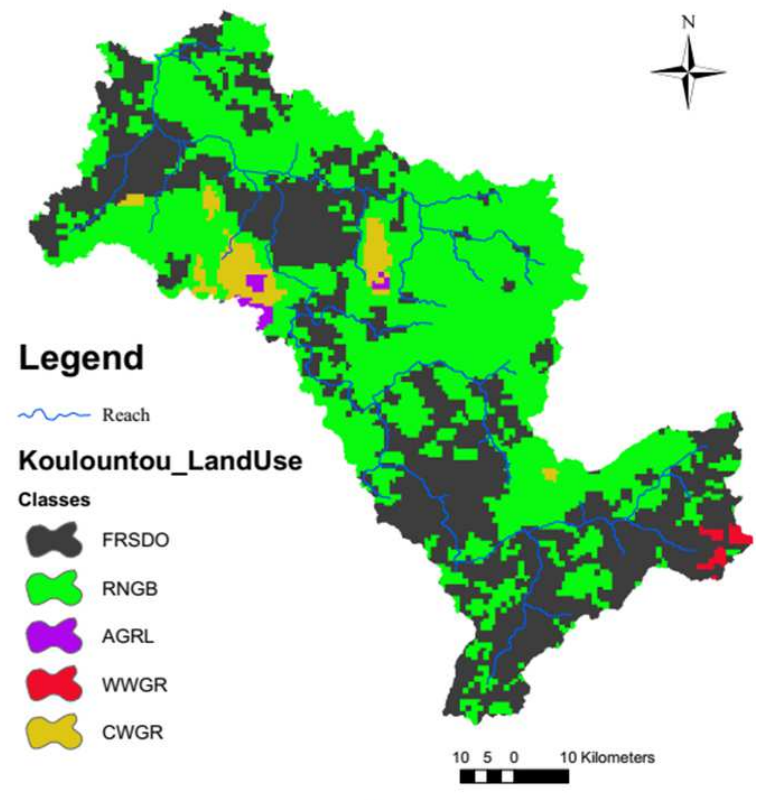

(b)

Figure 4. Land-use map distribution of: (a) the Niandouba Dam watershed and (b) the Koulountou watershed. 
Table 3. The area occupied by land use map.

\begin{tabular}{|c|c|c|c|}
\hline Land-use map & & \%Watershed Area & \\
\hline Koulountou River Basin at PNNK & $\begin{array}{l}\text { Kayanga River basin at } \\
\text { Niandouba Dam entrance }\end{array}$ & $\begin{array}{l}\text { Koulountou River Basin at } \\
\text { PNNK }\end{array}$ & $\begin{array}{l}\text { Kayanga River basin at } \\
\text { Niandouba Dam entrance }\end{array}$ \\
\hline FRSDO (Forest-Deciduous) & FRSDO (Forest-Deciduous) & 40.8 & 45.14 \\
\hline RNGB (Range-Brush) & RNGB (Range-Brush) & 55.51 & 51.8 \\
\hline AGRL (Agricultural Land-Generic) & -------- & 0.46 & 0 \\
\hline WWGR (Western Wheatgrass) & -------- & 0.47 & 0 \\
\hline CWGR (Crested Wheatgrass) & CWGR (Crested Wheatgrass) & 2.75 & 3.05 \\
\hline
\end{tabular}

\subsubsection{Soil Types}

The soil types intervene in the speed of rising of the floods and on their volume. Indeed, the rate of infiltration, the capacity of retention, the initial losses, the coefficient of runoff $(\mathrm{Cr})$ are functions of the type of Sol and its thickness. The soil map is illustrated in Figure 5. The comparison of the main soil classes of the Koulountou River Basin at PNNK and of Kayanga River basin at Niandouba Dam entrance are present in Table 4. Leptosols predominates in the Koulountou river basin at PNNK (79.2\%), followed by Regosols $(11.99 \%)$, while Acrisols dominates in the Kayanga river basin at the entrance to the Niandouba dam. (47\%) also followed by Regosols (19.03\%).

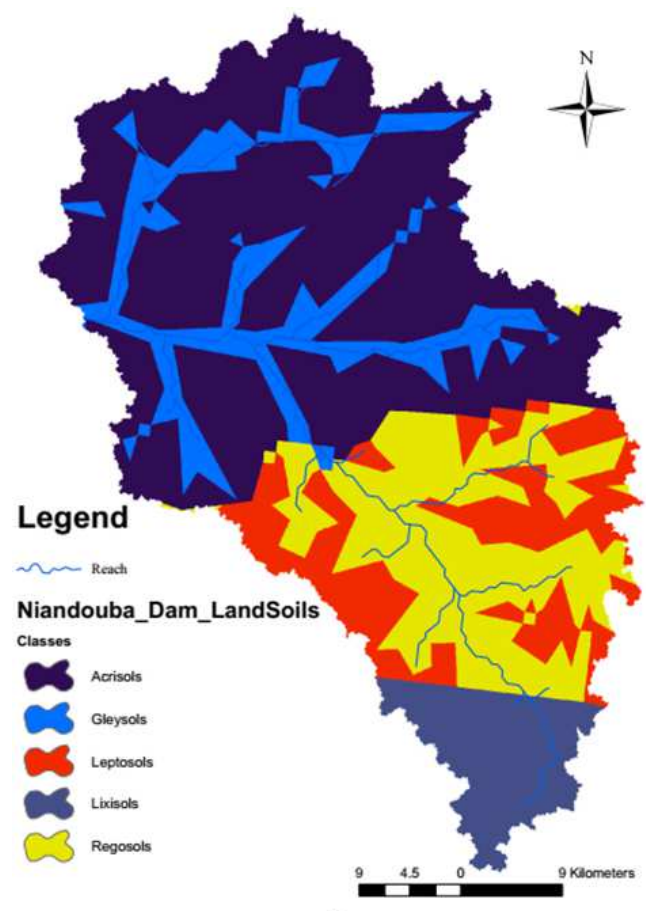

(a)



(b)

Figure 5. Map of soil distribution of: (a) the Niandouba Dam watershed and (b) the Koulountou watershed.

Table 4. The area occupied by Soil map.

\begin{tabular}{llll}
\hline Soil map & & \%Watershed Area & \\
\hline $\begin{array}{l}\text { Koulountou River Basin at } \\
\text { PNNK }\end{array}$ & $\begin{array}{l}\text { Kayanga River basin at Niandouba Dam } \\
\text { entrance }\end{array}$ & $\begin{array}{l}\text { Koulountou River Basin at } \\
\text { PNNK }\end{array}$ & $\begin{array}{l}\text { Kayanga River basin at Niandouba } \\
\text { Dam entrance }\end{array}$ \\
\hline------- & Acrisols & 0 & 47 \\
ambisols & $-----------~$ & 4.78 & 0 \\
Fluvisols & -------- & 0.37 & 0 \\
Gleysols & Gleysols & 0.92 & 13.18 \\
Leptosols & Leptosols & 79.2 & 13 \\
Lixisols & Lixisols & 2.72 & 7.79 \\
Regosols & Regosols & 11.99 & 19.03 \\
\hline
\end{tabular}

\subsection{Sensitivity Analyses}

SWAT model consists generally of more than 23 parameters [32]. We present these parameters in table 5. But only a few are required to run SWAT. Sensitivity analyses allow selecting the most sensitive parameters to run SWAT. The parameters used for the flow were selected based on the 
literature and the SWAT documentation. The initial simulation to determine the sensitivity of the model to different parameters was performed using default parameter values [33]. The appropriate parameterization can result in earlier and correct model calibration. The aim of sensitivity analysis is to determine the cause-and-effect relation between model parameters and modeling results [17]. Some authors perform sensitivity analysis by using different methods, for example, the SWAT-CUP [34], which used the multiple regression analysis to determine the sensitive parameters and the influence coefficient methods, which is one of the most common methods for computing sensitivity coefficients in surface and groundwater problems [35]. In this study, we have used the method that evaluates the sensitivity by changing each of the independent parameters, one at a time. A sensitivity coefficient represents the change of a response variable that is caused by a unit change of an explanatory variable while holding the rest of the parameter's constant.
The sensitivity coefficients can be positive or negative. A negative coefficient indicates an inversely proportional relationship between a response variable and an explanatory parameter [35]. The normalized sensitivity coefficient is called the sensitivity index and it is given by (9):

$$
S_{i}=\frac{P_{m}}{R_{m}} \frac{\Delta R}{\Delta P}
$$

Where $S_{i}$ the sensitivity index, $P_{m}$ and $R_{m}$ the mean of lowest and highest values parameter and response variable. with:

$$
\frac{\Delta R}{\Delta P}=\frac{R\left(P_{1}, P_{2}, \ldots, P_{i}+\Delta P_{i}, \ldots, P_{N}\right)}{\Delta P_{i}}-\frac{R\left(P_{1}, P_{2}, \ldots, P_{i}, \ldots, P_{N}\right)}{\Delta P_{i}}
$$

Where $R$ the response variable, $P$ the independent parameter, and $N$ the number of parameters.

\begin{tabular}{|c|c|c|}
\hline Parameter & Description & Min-Max interval \\
\hline \multicolumn{3}{|l|}{ Soil (.sol) } \\
\hline SOL Z & Depth to Bottom of first soil layer ( $\mathrm{mm}$ ) & {$[0.1 ; 3500]$} \\
\hline SOL BD & Moist bulk density of first soil layer $\left(\mathrm{Mg} / \mathrm{m}^{3}\right)$ & {$[0.9 ; 2.5]$} \\
\hline SOL_AWC & Available water capacity of first soil layer $(\mathrm{mm} / \mathrm{mm})$ & {$[0 ; 1]$} \\
\hline SOL_CBN & Organic carbon content of first soil layer (\%) & {$[0.05 ; 10]$} \\
\hline SOL_K & Saturated hydraulic conductivity of first soil layer $(\mathrm{mm} / \mathrm{hr})$ & {$[0 ; 2000]$} \\
\hline \multicolumn{3}{|l|}{ Subbasin (sub) } \\
\hline CH_K1 & Effective hydraulic conductivity in tributary channel alluvium $(\mathrm{mm} / \mathrm{hr})$ & {$[0 ; 300]$} \\
\hline CH_N1 & Manning's " $n$ " value for the tributary channels & {$[0.01 ; 30]$} \\
\hline \multicolumn{3}{|l|}{ HRĒ (.hur) } \\
\hline SLSUBBSN & Average slope length (m) & {$[10 ; 150]$} \\
\hline OV_N & Manning's " $\mathrm{n}$ " value for overland flow & {$[0.01 ; 30]$} \\
\hline LAT_TTIME & Lateral flow travel time (days) & {$[0 ; 180]$} \\
\hline CANMX & Maximum canopy storage $\left(\mathrm{mm} \mathrm{H}_{2} \mathrm{O}\right)$ & {$[0 ; 100]$} \\
\hline ESCO & Soil evaporation compensation factor & {$[0 ; 1]$} \\
\hline EPCO & Plant uptake compensation factor & {$[0 ; 1]$} \\
\hline SURLAG & Surface runoff lag time (days) & {$[0 ; 24]$} \\
\hline \multicolumn{3}{|l|}{ Routing (.Rte) } \\
\hline CH_N2 & Manning's " $n$ " value for the main channel & {$[-0.01 ; 0.3]$} \\
\hline $\mathrm{CH}_{-}^{-} \mathrm{K} 2$ & Effective hydraulic conductivity in main channel alluvium $(\mathrm{mm} / \mathrm{hr})$ & {$[-0.01 ; 500]$} \\
\hline \multicolumn{3}{|c|}{ Groundwater (.gw) } \\
\hline GW_DELAY & Groundwater delay (days) & {$[0 ; 500]$} \\
\hline ALPHA_BF & Baseflow alpha factor (days) & {$[0 ; 1]$} \\
\hline GWQMIN & Threshold depth of water in the shallow aquifer for return flow to occur $\left(\mathrm{mm} \mathrm{H}_{2} \mathrm{O}\right)$ & {$[0 ; 5000]$} \\
\hline GW_REVAP & Groundwater "revap" coefficient & {$[0.02 ; 0.2]$} \\
\hline REVAPMN & Threshold depth of water in the shallow aquifer for "revap" to occur $\left(\mathrm{mm} \mathrm{H}_{2} \mathrm{O}\right)$ & {$[0 ; 1000]$} \\
\hline RCHRG_DP & Deep aquifer percolation fraction & {$[0 ; 1]$} \\
\hline \multicolumn{3}{|c|}{ Management (.mgt) } \\
\hline $\mathrm{CN} 2$ & Initial Soil Conservation Service SCS runoff curve number for moisture condition II & {$[35 ; 98]$} \\
\hline
\end{tabular}

Table 5. The parameters identified as significant by the sensitivity analysis.

\subsection{Criteria for Model Evaluation}

For scientifically four quantitative statistics be used in model performance evaluation in watershed simulations: The Nash-Sutcliffe efficiency (NSE), Coefficient of determination $\left(\mathrm{R}^{2}\right)$, percent bias (PBIAS) and standard deviation Ratio (RSR).

The Nash-Sutcliffe efficiency (NSE) is defined as one minus the sum of the absolute squared differences between the predicted and observed values normalized by the variance of the observed values during the period under investigation. If the measured value is the same as all predictions, NSE is 1. If the NSE is between 0 and 1 , it indicates deviations between measured and predicted values. It is calculated as in (11)

$$
N S E=1-\frac{\sum_{i=1}^{n}\left(Q_{i}^{o b s}-Q_{i}^{s i m}\right)^{2}}{\sum_{i=1}^{n}\left(Q_{i}^{o b s}-Q_{m e a n}^{o b s}\right)^{2}}
$$

Where $Q_{i}^{\text {obs }}$ the $\mathrm{i}^{\text {th }}$ observed streamflow, $Q_{i}^{\text {sim }}$ the $\mathrm{i}^{\text {th }}$ simulated streamflow, $Q_{\text {mean }}^{\text {obs }}$ the mean of observed streamflow.

The coefficient of determination $R^{2}$ in observed data explains 
the fraction of the total variance. The coefficient of determination value ranges from 0 to 1 . It is calculated as in (12)

$$
R^{2}=\left(\frac{\sum_{i=1}^{n}\left(Q_{i}^{\text {obs }}-Q_{\text {mean }}^{\text {obs }}\right)\left(Q_{i}^{\text {sim }}-Q_{m e a n}^{\text {sim }}\right)}{\sqrt{\sum_{i=1}^{n}\left(Q_{i}^{\text {obs }}-Q_{\text {mean }}^{\text {obs }}\right)^{2}} \sqrt{\sum_{i=1}^{n}\left(Q_{i}^{\text {sim }}-Q_{\text {mean }}^{\text {sim }}\right)^{2}}}\right)^{2}
$$

Where $Q_{i}^{o b s}$ the $\mathrm{i}^{\text {th }}$ observed streamflow, $Q_{i}^{s i m}$ the $\mathrm{i}^{\text {th }}$ simulated streamflow, $Q_{\text {mean }}^{\text {obs }}$ the mean of observed streamflow, $Q_{\text {mean }}^{\text {sim }}$ the mean of simulated streamflow.

Percent bias (PBIAS) measures the average negative deviation of the predicted data from the observed data with an optimum value of $0 \%$ meaning no deviation. It is calculated as follows (13)

$$
P B I A S=\frac{\sum_{i=1}^{n}\left(Q_{i}^{o b s}-Q_{i}^{s i m}\right)}{\sum_{i=1}^{n}\left(Q_{i}^{o b s}\right)} \times 100
$$

Where $Q_{i}^{\text {obs }}$ the $\mathrm{i}^{\text {th }}$ observed streamflow, $Q_{i}^{\text {sim }}$ the $\mathrm{i}^{\text {th }}$ simulated streamflow.

The RSR is an error-index that standardizes the root mean square error (RMSE) using the observations' standard deviation $\left(\mathrm{STDEV}_{\mathrm{obs}}\right)$. RSR ranges between 0 and 1 , with low values indicating good model performance. RSR is calculated as in (14)

$$
R S R=\frac{\sqrt{\sum_{i=1}^{n}\left(Q_{i}^{o b s}-Q_{i}^{\text {sim }}\right)^{2}}}{\sqrt{\sum_{i=1}^{n}\left(Q_{i}^{\text {obs }}-Q_{\text {mean }}^{\text {obs }}\right)^{2}}}
$$

Where $Q_{i}^{\text {obs }}$ the $i^{\text {th }}$ observed streamflow, $Q_{i}^{\text {sim }}$ the $i^{\text {th }}$ simulated streamflow, $Q_{\text {mean }}^{\text {obs }}$ the mean of observed streamflow

\section{Results}

The results of the parameters sensitivity analysis for the Koulountou basin are presented in Table 6. Only 20 parameters have been found to be significant among the 23 . In column 3, parameters have been classified from the most sensitive to the less sensitive. According to this table, the most sensitive parameter is the SOL_K, and the less sensitive one is the SURLAG. BSN.

Table 6. The selected and the rang for the parameter sensitivity analysis.

\begin{tabular}{lll}
\hline parameter & values of $\Delta \mathbf{R} / \Delta \mathbf{P}$ & Rang \\
\hline SOL_K & $5.89 \mathrm{E}+10$ & 1 \\
SOL_Z & $9.36 \mathrm{E}+09$ & 2 \\
WQMIN. GW & $3.36 \mathrm{E}+09$ & 3 \\
CH_K1 & $3.74 \mathrm{E}+08$ & 4 \\
CN2. MGT & $2.14 \mathrm{E}+08$ & 5 \\
REVAPMIN. GW & $1.20 \mathrm{E}+08$ & 6 \\
DELAY. GW & $4.46 \mathrm{E}+07$ & 7 \\
SLSUBBSN & $1.19 \mathrm{E}+07$ & 8 \\
CANMX & $1.20 \mathrm{E}+06$ & 9 \\
SOL_AWC & $1.75 \mathrm{E}+04$ & 10 \\
SOL_BD & $8.75 \mathrm{E}+03$ & 11 \\
ESCO & $2.99 \mathrm{E}+03$ & 12 \\
SOL_CBN & $1.69 \mathrm{E}+03$ & 13 \\
LAT_TTIME & $1.26 \mathrm{E}+03$ & 14 \\
CH_N1 & $2.46 \mathrm{E}+02$ & 15 \\
\hline
\end{tabular}

\begin{tabular}{lll}
\hline parameter & values of $\Delta \mathbf{R} / \Delta \mathbf{P}$ & Rang \\
\hline OV_N & $2.46 \mathrm{E}+02$ & 15 \\
RCHRG_DP. GW & $2.12 \mathrm{E}+02$ & 17 \\
ALPHA_BF. GW & $4.89 \mathrm{E}+01$ & 18 \\
REVAP. GW & $4.71 \mathrm{E}+01$ & 19 \\
SURLAG. BSN & $1.53 \mathrm{E}+01$ & 20 \\
EPCO & $0.00 \mathrm{E}+00$ & 21 \\
CH-N2 & $0.00 \mathrm{E}+00$ & 21 \\
CH-K2 & $0.00 \mathrm{E}+00$ & 21 \\
\hline
\end{tabular}

\subsection{Calibration on Koulountou Watershed}

The calibration process consists of controlling the values of the model parameters so that the simulated values approximate those observed, thus representing better the simulated process. In this study, we have unfortunately only two years of observed runoff on the Koulountou basin at the National Parc of Niokolo Koba stream gauge: 2001-2002. The first year has been used for calibration, the second for validation.

Once the most sensitive model parameters have been identified, they have been used for the calibration of the SWAT models. Anyways, the model calibration process was performed for a one year $(01 / 01 / 2001$ and $31 / 12 / 2001)$, in the same period as the sensitivity analysis period. Table 7 summarizes the values of the sensitive parameters after calibration.

Table 7. The parameter after calibration

\begin{tabular}{lll}
\hline Parameter & $\begin{array}{l}\text { Value before } \\
\text { calibration }\end{array}$ & $\begin{array}{l}\text { Value after } \\
\text { calibration }\end{array}$ \\
\hline SOL_K & 8.41 & 1300 \\
SOL_Z & 300 & 740 \\
WQMIN. GW & 1000 & 1000 \\
CN2.MGT & 74 & 70 \\
REVAPMIN. GW & 750 & 900 \\
DELAY. GW & 31 & 31 \\
SLSUBBSN & 91.5 & 120 \\
CANMX & 0 & 100 \\
SOL_AWC & 0.062 & 0.46 \\
SOL_BD & 1.3 & 0.95 \\
ESCO & 0.95 & 0.1 \\
SOL_CBN & 1.6 & 0.1 \\
LAT_TTIME & 0 & 100 \\
OV_N & 0.15 & 15 \\
\hline
\end{tabular}

In table 8, we present the statistical criteria for model evaluation after calibration. According to the values of table 8 , the criteria of evaluation are:

Table 8. Statistic summary for the calibration.

\begin{tabular}{lllll}
\hline criteria & NSE & $\mathbf{R}^{2}$ & PBIAIS & RSR \\
\hline value & 0.87 & 0.87 & $-1.6 \%$ & 0.36 \\
\hline
\end{tabular}

We present in Figure 6 the plot of calculated and observed hydrographs of runoff for the calibration period. According to this plot, the rising part and the recession of simulated hydrographs are not well restituted. This is probably due to the very limited number of years for the observed runoff data. 


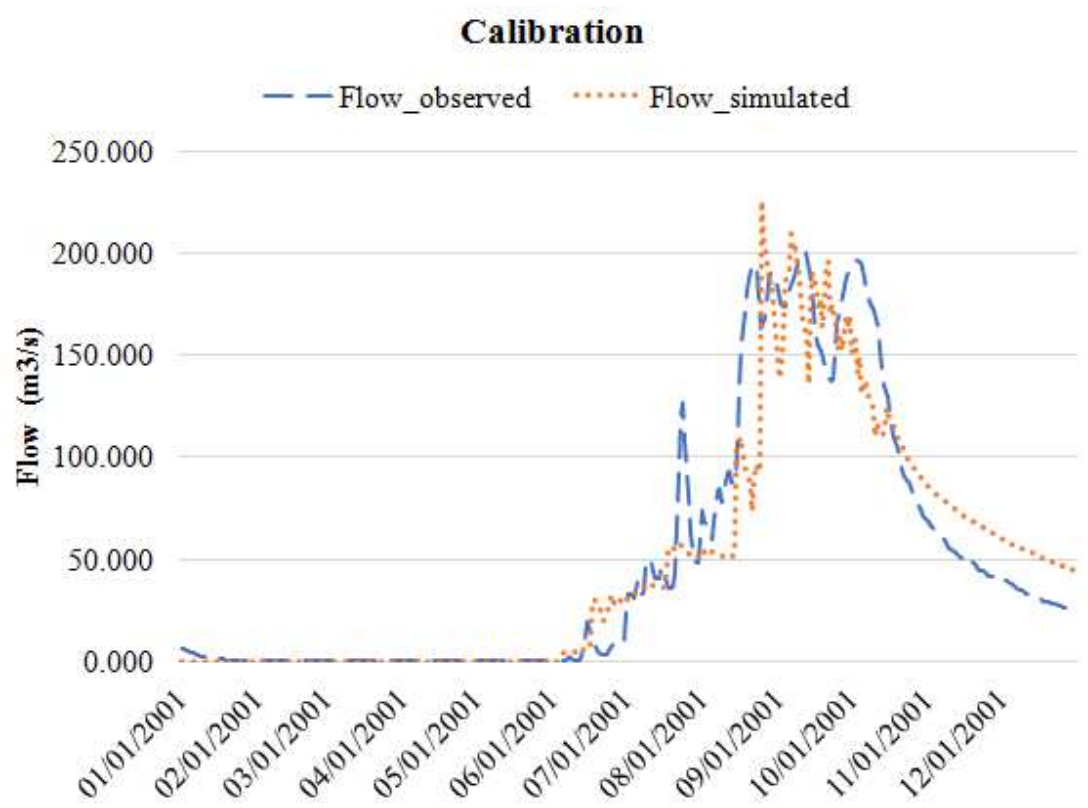

Figure 6. The hydrograph of simulated and observed daily flow for calibration.

\subsection{Validation on Koulountou Watershed}

The parameters calculated for the calibration period are used to validate the model with runoff data on the calibration period from $01 / 01 / 2002$ to $31 / 12 / 2002$. The values of the criteria for model evaluation are presented in Table 9.

Table 9. Statistic summary for the validation.

\begin{tabular}{lllll}
\hline criteria & NSE & $\mathbf{R}^{2}$ & PBIAIS & RSR \\
\hline value & 0.62 & 0.77 & $+35.9 \%$ & 0.62 \\
\hline
\end{tabular}

Plots of observed and simulated flows during the validation period are presented in Figure 7.

\section{Validation}



Figure 7. The hydrograph of daily simulated and observed flow for validation.

The evaluation criteria of the model seem to indicate a good match between observed flow rates and flow rates calculated from the parameters obtained after calibration. The plots show large differences between calculated and observed flows. The periods of rising and fall of the water are poorly taken into account, and the model overestimates the high values and flows. However, the general pattern of the calculated hydrograph is reproduced.

\subsection{Application to Kayanga River Basin Upstream Niandouba Dam}

We then use the parameters of the SWAT model calibrated and validated on the Koulountou River basin to simulate the runoff hydrograph in the Kayanga River Basin at the entrance Niandouba Dam for the period 1999 to 2000. We show in Figure 8 the plots of the simulate runoff hydrograph. 


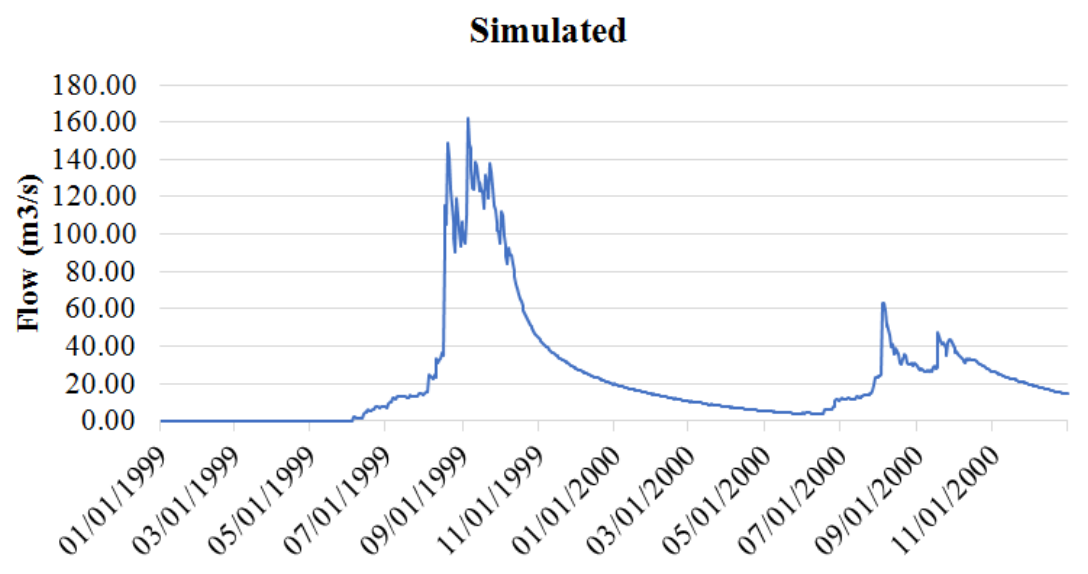

Figure 8. The hydrograph of daily simulated for the Niandouba Dam watershed.

\subsection{Discussions}

The initialization was performed during the period 19992000, the calibration during the year 2001 and the validation during the year 2002. Among the 23 parameters of the calibration step, 20 have been found to be sensitive according the sensitivity analysis. The most sensitive is the saturated hydraulic conductivity of first soil layer (SOL_K) with a value of $1300 \mathrm{~mm} / \mathrm{hr}$. Four criteria have been selected for goodness of fit: NES, R², PBIAS and RSR. The values of these criteria are respectively $0.87,0.87,-1.6 \%$, 0.36 for calibration step and $0.62,0.77,+35.9 \%, 0.62$ for validation step. We have plotted simulated and observed daily flows for the calibration and validation period (Figures 6 and 7). For the calibration period, the calculated flows match the observed flow, except for the recession. For the validation step, the differences between the observed and calculated flows are greater, in particular for the periods of floods and recessions. This is due to the fact that the period of study is too short. We present an example of application of the parameters calibrated and validated on the Koulountou basin to generate flows in the ungauged basin upstream Niandouba Dam. This method constitutes an alternative when there is no flow measurement on an ungauged watershed.

\section{Conclusion and Perspectives}

This study was intended to simulate the hydrology of the ungauged watershed using parameters of a hydrological rainfall-runoff model calibrated and validated on a gauged watershed. The SWAT model has been selected. SWAT model parameters have been calibrated and validated on the Koulountou basin. Criteria of goodness of fit used to evaluate the calibration and validation show that these parameters are relatively well-suited. They were used to reconstruct the input flows in the Niandouba dam. Even if the results have not been validated with observations, this method constitutes a solution for ungauged basins.

For a better application of this we recommend

i. The use of longer time series of flow and runoff in the calibration and validation steps

ii. The development of new regionalization approaches to explore the links between geographic proximity and hydrological similarity between watersheds,

iii. The search for new physical descriptors capable of better describing the hydrological behavior of watersheds and capturing the information necessary to transfer to ungauged basins.

\section{References}

[1] DACOSTA, Honoré; COLY, Adrien; et SOUMARÉ, Pape Ousmane. 2002. Adéquation de l'offre et de la demande en eau: Dynamique hydrologique de l'Anambé (Sénégal). Marseille: IRD Éditions, (généré le 23 avril 2017). ISBN: 9782709918176. DOI: 10.4000/books.irdeditions. 8571 .

[2] Diouf M. 2013. Cohabitation entre petits producteurs et grands exploitants agricoles sur les terres irriguées: cas de la sodévol et des petits producteurs du périmètre aménagé du bassin de l'Anambé au Sénégal. Union Internationale pour la Conservation de la Nature (UICN-Sénégal).

[3] SODAGRI. 2015. Rapport annuel d'activités. Société de développement agricole et industriel du Sénégal. Ministère de l'Agriculture et de l'Equipement Rural (MAER). Sénégal.

[4] IDEV-ic. 2010. Etat des lieux autour des barrages de Niandouba et du Confluent au Sénégal

[5] Marian Amoakowaah Osei., Leonard Kofitse Amekudzi., David Dotse Wemegah., Kwasi Preko., Emmanuella Serwaa Gyawu., and Kwasi Obiri-Danso. 2018. Hydro-Climatic Modelling of an Ungauged Basin in Kumasi, Ghana. journal Hydrol. Earth Syst. Sci. https://doi.org/10.5194/hess-2017-729.

[6] Razna Rahim., Sheena Hassan. 1014. Stream Flow Prediction in Ungauged Basin: Calibration and Validation Analysis Using SWATCUP. International journal of scientific and engineering research, volume 5, issue 7, ISSN 2229-5518.

[7] Ammar Rafiei Emam., Martin Kappas., Linh Hoang Khanh Nguyen., Tsolmon Renchin. 2016. Hydrological Modeling in an Ungauged Basin of Central Vietnam Using SWAT Model. journal Hydrol. Earth Syst. Sci. doi: 10.5194/hess-2016-44, 2016. 
[8] Himanshu Mishra., Derrick Mario Denis., Shakti Suryavanshi., Mukesh Kumar., Santosh Kumar Srivastava., Anjelo Francis Denis., Rajendra Kumar. 2017. Hydrological simulation of a small ungauged agricultural watershed Semrakalwana of Northern India. Appl Water Sci (2017) 7: 2803-2815 DOI 10.1007/s13201-017-0531-7.

[9] H. Sellami., I. La Jeunesse., S. Benabdallah., N. Baghdadi., and M. Vanclooster. 2014. Uncertainty analysis in model parameters regionalization: a case study involving the SWAT model in Mediterranean catchments (Southern France). Journal Hydrol. Earth Syst. Sci., 18, 2393-2413. doi: 10.5194/hess-18-2393-2014.

[10] Maryam Alipour., Majid Hosseini. 2018. Simulation of surface runoff in Karaj dam basin, Iran. Applied Water Science. https://doi.org/10.1007/s13201-018-0782-y.

[11] U.S. Army Corps of Engineers Hydrologic Engineering Center (USACE-HEC) (2009), HEC-HMS Hydrologic Modeling System - User's Manual, USACE-HEC, Davis, CA.

[12] M. Butts, J. Overgaard, D. Graham, A. Dubicki, K. Strońska, W. Szalinksa, A. Lewandowski, T. Olszewski, T. Kolerski, O. Larsen. 2005. Process-based Hydrological Modelling Framework MIKE SHE for Flood Forecasting on the Upper and Middle Odra. ICID 21st European Regional Conference. Frankfurt (Oder) and Slubice - Germany and Poland.

[13] Seibert, J., 1999. Conceptual runoff models - fiction or representation of reality? Acta Univ. Ups., Comprehensive Summaries of Uppsala Dissertations from the Faculty of Science and Technology 436. 52 pp. Uppsala. ISBN 91-5544402-4.

[14] Christophe Bouvier, Anne Crespy, Agnes L'Aour-Dufour, François-Noel Crès, François Delclaux, Arthur Marchandise, 2010. Modélisation hydrologique distribuée - Plate-forme ATHYS. In. Traité d'Hydraulique Environnementale, volume 9: Logiciels d'Ingénierie du cycle de l'eau, chapitre 7 , $115-134$

[15] Arnold, J. G., Engel, B. A., and Srinivasan, R., 1993. Continuous-time, grid cell watershed model. Proc. of the 1819 June 1993 Conf. Spokane, Washington, 267-278.

[16] Arnold J. G., Srinivasan R., Muttiah R. S. and Williams J. R., 1998. "Large Area Hydrological Modeling and Assessment. Part I: Model Development," Journal of the American Water Resources Association, Vol. 34, No. 1, pp. 73-89. doi: 10.1111/j.1752-1688.1998.tb05961.x..

[17] Smarzyńska K., Miatkowski Z. 2016. Calibration and validation of SWAT model for estimating water balance and nitrogen losses in a small agricultural watershed in central Poland. Journal of Water and Land Development. No. 29 p. 31-47. DOI: 10.1515/jwld-2016-0010.

[18] Rafael A. Almeida., Silvio B. Pereira., Daniel B. F. Pinto. 2018. Calibration and validation of the swat hydrological model for the mucuri river basin. Journal of the Brazilian association of Agricultural Engineering. http://dx.doi.org/10.1590/1809-4430-Eng.Agric.v38n1p55$63 / 2018$.

[19] Lucas M. Pontes., Marcelo R. Viola., Marx L. naves Silva., Diêgo F. A. Bispo., Nilton Curi. 2016. Hydrological modeling of tributaries of Cantareira system, south east brazil, with the swat model. Journal of the Brazilian association of
Agricultural Engineering. http://dx.doi.org/10.1590/18094430-Eng.Agric.v36n6p1037-1049/2016

[20] Bounhieng Vilaysane., Kaoru Takara., Pingping Luo., Inthavy Akkharath., WeiliDuan. 2015. Hydrological stream flow modeling for calibration and uncertaintyanalysis using SWAT model in the Xedone river basin, Lao PDR. Science Direct Procedia Environmental Sciences 28 (2015) 380 - 390. doi: 10.1016/j.proenv.2015.07.047.

[21] Saly Sambou, Honoré Dacosta et Jean-Emmanuel Paturel, 2018. Variabilité spatio-temporelle des pluies de 1932 à 2014 dans le bassin versant du fleuve Kayanga/Gêba (République de Guinée, Sénégal, Guinée-Bissau). Physio-Géo, Volume 12 $-1,61-78$.

[22] Oumar SENE, 1992. Ecoulement, crues et étiages dans le bassin versant de la Koulountou. Travail d'étude et de recherche mémoire de maitrise. Laboratoire d'hydrologie, département de géographie, Faculté des Lettres et Sciences Humaines, UCAD.

[23] Oeurng, C. and Sauvage, Sabine and Sanchez-Pérez, JoséMiguel 2011. Assessment of hydrology, sediment and particulate organic carbon yieldin a large agricultural catchment using the SWAT model. Journal of Hydrology, vol. 401 (n`3-4). pp. 145-153. ISSN 0022-1694

[24] Raksmey Ang., Chantha Oeurng. 2018. Simulating streamflow in an ungauged catchment of Tonlesap Lake Basin in Cambodia using Soil and Water Assessment Tool (SWAT) model. National Water Research Center. Production and hosting by Elsevier B. V. Water Science 32 89-101. https://doi.org/10.1016/j.wsj.2017.12.002.

[25] A. M. Epelde, I. Cerro, J. M. Sánchez-Pérez, S. Sauvage, R. Srinivasan \& I. Antigüedad, 2015. Application of the SWAT model to assess the impact of changes in agricultural management practices on water quality, Hydrological Sciences Journal, 60: 5, 825-843, DOI: 10.1080/02626667.2014.967692.

[26] Abdelhamid Fadil, Hassan Rhinane, Abdelhadi kaoukaya, Youness kharchaf, Omar Alami Bachir, 2011. Hydrologic Modeling of the Bouregreg Watershed (Morocco Using GIS et SWAT Model. Journal of Geographic information System, 3, 279-289, doi: 10.4236/jgis.2011.34024.

[27] Mendas A., Errih M., Benhanifia K., Maidi M., Rahmani M. A. 2007. Hydrologic model and GIS to estimate hydrologic balance at watershed scale - Application to the watershed of Macta (Western Algerian). Proceedings of the 2nd IASME / WSEAS International Conference on Water Resources, Hydraulics \& Hydrology, Portoroz, Slovenia.

[28] Abbasa, N., Wasimia, S. A. and Al-Ansari, N. (2016) Assessment of Climate Change Impact on Water Resources of Lesser Zab, Kurdistan, Iraq using SWAT Model. Engineering, 8, 697-715. http://dx.doi.org/10.4236/eng.2016.810064.

[29] Abbas, N., Wasimi, S. A. and Al-Ansari, N. (2016) ModelBased Assessment of Climate Change Impact on Isaac River Catchment, Queensland. Engineering, 8, 460-470. http://dx.doi.org/10.4236/eng.2016.87043.

[30] S. L. Neitsch, J. G. Arnold, J. R. Kiniry, J. R. Williams. 2009. Soil and Water Assessment Tool Theoretical Documentation Version 2009. Texas Water Ressources Institute Technical Report No. 406. Texas A\&M University System, College Station, Texa, USA. 
[31] Dao Nguyen Khoia, Vu Thi Thom. 2015. Parameter uncertainty analysis for simulating streamflow ina river catchment of Vietnam. Journal homepage: www.elsevier.com/locate/gecco, Global Ecology and Conservation 4, 538-548. http://dx.doi.org/10.1016/j.gecco.2015.10.007.

[32] Natalja Čerkasova, Georg Umgiesser, Ali Ertürk, 2018. Development of a hydrology and water quality model for a large transboundary river watershed to investigate the impacts of climate change- A SWAT application. Vol. 124, pp 99-115. https://doi.org/1à.1016/j.ecoleng.2018.09.025.

[33] Da Silva, M. G., de Oliveira de Aguiar Netto, A., de Jesus Neves, R. J., do Vasco, A. N., Almeida, C. and Faccioli, G. G.
(2015) Sensitivity Analysis and Calibration of Hydrological Modeling of the Watershed Northeast Brazil. Journal of Environmental Protection, 6, 837-850. http://dx.doi.org/10.4236/jep.2015.68076.

[34] Abbaspour, K. C., 2011. Swat-Cup2: SWAT Calibration and Uncertainty Programs Manual Version 2, Department of Systems Analysis, Integrated Assessment and Modelling (SIAM), Eawag. Swiss Federal Institute of Aquatic Science and Technology, Duebendorf, Switzerland. 106 p.

[35] Jha, Manoj K., 2009. "Hydrologic Simulations of the Maquoketa River Watershed Using SWAT". CARD Working Papers. 530. http://lib.dr.iastate.edu/card_working papers/530. 